\title{
'n Kritiese evaluasie van Colin Brown se studie: Miracles and the critical mind
}

EJ Vledder

\begin{abstract}
A critical evaluation of Colin Brown's study: Miracles and the critical mind

As a historical survey of the viewpoints regarding miracles throughout the ages, Miracles and the critical mind of Colin Brown can be highly recommended as a reference work. In this lies its value. Brown has an interesting viewpoint. He states that miracles can only be interpreted when asked what the evangelists themselves meant by it in their Gospels. But to my mind, Brown does not successfully show that miracles enable us to make sense of the Gospels as history. The reason is that he cannot conclusively prove that miracles are historical facts, and thus the Gospels are history as well. Miracles should be accepted by faith. In this respect he stands fully in an age-old tradition, and as such does not contribute much new towards the debate about miracles. To follow is a critical evaluation of the abovementioned study.
\end{abstract}

\section{DIE AARD EN DIE BEDOELING VAN DIE STUDIE}

Wanneer daar vandag oor wonders gepraat word, is dit nie 'n nuwe onderwerp nie. Die debat oor die moontlikheid van wonders in die hede, asook die feitelikheid (historisiteit) van die wonderwerke van Jesus, is al baie eeue aan die gang. 'n Uitspraak oor die bestaan, al dan nie, van wonders, kan nooit los gesien word van uitsprake uit die verlede nie. Wanneer daar gesoek word na uitsprake en standpunte uit die verlede oor wonders, bevind ' $n$ mens jou gou in ' $n$ doolhof van standpunte van wyduiteenlopende aard. In hierdie doolhof het Colin Brown* probeer orde skep en het hy die standpunte ten opsigte van wonders oor eeue heen uitgesorteer en gesistematiseer.

Brown se studie is hoofsaaklik histories van aard. Hierin lê myns insiens sy groot waarde. Hy het die mees verteenwoordigende uitsprake ten opsigte van wonders probeer uitsorteer en chronologies weergegee. Om met integriteit 'n mening oor wonders te waag, was dit vir hom nodig om 'n hernieude ondersoek na argumente ten gunste * Brown, C 1984. Miracles and the critical mind. Grand Rapids: Eerdmans. 
daarvan te doen en daarteen te doen (1984: vi). Omdat die debat oor wonders nooit in 'n vakuum plaasvind nie, gee hy doelbewus beide teologiese en filosofiese argumente weer.

\section{DRIE BASIESE STANDPUNTE}

Oor die moontlikheid dat Jesus wonders kon doen, twyfel Brown hoegenaamd nie. Trouens, hy wy baie aandag aan die afweer van die 'skeptikus' (soos hy hom noem), David Hume (1711-1776). Hy staan 'n volledige hoofstuk aan David Hume af. Hoewel Hume nie die eerste skeptikus was wat teen die bestaan van wonders was nie, meen Brown dat sy argumente vanaf die sewentiende eeu tot vandag toe nog groot aandag geniet en invloed uitoefen (1984: 79). Hume se kort artikel 'On Miracles', beslaan slegs 20 hladsye van sy boek Enquiry concerning human understanding (1748). Tog is dié artikel geweldig belangrik. Die artikel bestaan hoofsaaklik uit twee dele. Deel I behandel die sogenaamde a priori-oorwegings. Deel II gaan oor die sogenaamde aposteriori-oorwegings vir die bestaan van wonders.

In Deel I word dit beredeneer dat wonders wetenskaplik onmoontlik is omdat dit op grond van die 'wette van die natuur' nie kan plaasvind nie. Hume het 'n drieledige doel gehad met sy argument: (1) om aan te toon dat dit 'n onoorkombare probleem is om uit die geskiedenis die historiese geloofwaardigheid ('veracity') van die wonders te bewys; (2) om die daaropvolgende onmoontlikheid aan te toon dat wonders vis apologie gebruik kan word met die oog daarop om die waarheid van enige godsdiens te demonstreer; en (3) om vervolgens aan te toon dat, alhoewel wonders wel 'n objek van geloof kan wees, dit nooit die basis daarvan kan wees nie (Brown 1984: 81).

Hume beskou die mens se ervaring as die enigste riglyn om 'n feit te bepaal. Hy stel dit so: '. . experience is our only guide in reasoning concerning matters of fact' (aangehaal deur Brown 1984: 81). Die kardinale toets vir enige gerapporteerde gebeurtenis is hoe waarskynlik die gebeurtenis in die lig van ons eie ervaring van gebeurlikhede uit die verlede is. Alhoewel daar geen direkte toegang meer tot gebeurtenisse uit die verlede is nie, moet daar tog 'n kriterium wees om die waarskynlikheid daarvan te bepaal. Die bepalende vir die waarskynlikheid van die gebeurlikhede uit die verlede is of daar enige analogie of ooreenkoms bestaan tussen die gerapporteerde gebeurtenisse en die gebeurtenisse in ons eie ervaringswerklikheid van hoe dinge gewoonlik gebeur. Teen hierdie agtergrond verwerp Hume die bestaan van 
wonders omdat dit onverenigbaar is met die wette van die natuur: 'A miracle is a violation of the laws of nature; and as a firm and unalterable experience has established these laws, the proof against a miracle, from the very nature of the fact, is as entire as any argument from experience can possibly be imagined' (aangehaal deur Brown 1984: 84).

Hume definieer ' $n$ wonder '... as transgression of a law of nature by a particular volition of the Deity, or by the interposition of some invisible agent' (aangehaal deur Brown 1984: 84). Daar bestaan geen ander agent of oorsaak om wonders te doen as God nie. Maar omdat die oorsake van gebeurtenisse nie aan die gevolge geken kan word nie, is God as oorsaak van wonders uitgesluit. Oorsake kan nie gesien word nie, slegs die opeenvolging van gebeurtenisse is sigbaar. Die oorsaak van 'n gebeurtenis is iets wat ons net in ons gedagtes 'voel'. Dit is dus die produk van die verbeelding. Daarom is Hume nie bereid om God as oorsaak van die wonders te erken nie.

Hume verwerp dus die bestaan van wonders (ook die wonders van Jesus) omdat (1) dit nie uit die getuienis van die verlede bewys kan word nie, (2) dit nie in ooreenstemming is met ons ervaringswerklikheid wat die wette van die natuur vasstel nie en (3) die oorsaak daarvan nie bepaal kan word nie, so ook nie God as oorsaak nie.

Deel II van Hume se argument handel oor die sogenaamde aposteriori-oorwegings vir die bestaan van wonders. Dit kom basies daarop neer dat die rasionele mens wonders nie kan aanvaar nie. Die rede hiervoor is dat: (1) die getuies van die beweerde wonders in die Nuwe Testament onbekwaam is, (2) die mens 'n voorliefde het om gebeurtenisse te oordryf en aan te dik, (3) wonders alleen by onkundige (ignorant) mense voorkom en (4) wonders van mededingende godsdienste (rival religions), mekaar uitkanselleer. Wonders kan as 't ware alleen aanvaar word as ons bereid is om ons intellek prys te gee (EJV).

Brown het tereg ernstige kritiek teen Hume (en by implikasie ook teen alle skeptici - EJV). Dit is vir Brown duidelik dat Hume geen historiese getuienis uit die verlede oor wonders in ag wil neem nie. Die rede is dat wonders by voorbaat beskou is as 'violations of the laws of nature' en daarom per definisie onmoontlik is (1984: 91). So gooi hy as 't ware die baba saam met die badwater uit. So is daar gebeurtenissse uit die verlede wat indruis teen ons 'firm and unalterable experience' en tog vandag aan psigosomatiese faktore toegeskryf kan word. Verder, wie stel hierdie 'firm and unalterable experience' vas? Brown meen tereg ook dat hy nie presies kan vasstel wat Hume met the laws of nature' bedoel nie. Hy weet nie watter kriteria Hume gebruik het om 
dit te bepaal nie. Dit lyk of Hume die ervaringswerklikheid van die mens gelykstel met die wette van die natuur. Verder vra Brown: Wie kan vandag eerlik sê dat hy die absolute grens van sy ervaringswerklikheid bereik het (met ander woorde dat sy ervaringswerklikheid nie meer uitgebrei kan word nie - EJV)? Kan hierdie grens nie van tyd tot tyd verbreed word nie? Brown reken dat dít wat met die eerste oogopslag die wette van die natuur weerspreek en dus onmoontlik lyk, later wel deel kan wees van iets wat by 'n breëre verstaan van die werklikheid inpas. Dit kan later wél inpas by 'n breëre ervaringswerklikheid.

Ook Hume se aposteriori-oorwegings is volgens Brown te losse veralgemenings. Die getuienis van 'n waarnemer van sekere gebeurlikhede uit die verlede kan dikwels méér betroubaar wees as eie ervaring, veral as dit ' $n$ geoefende waarnemer is. Verder kan 'n mens nie noodwendig ' $n$ ander se getuienis uitsluit omdat hy nie dieselfde opvoedkundige peil of kultuur as jyself het nie. (Dit getuig eerder van arrogansie as gegronde argumentering - EJV). Dit is duidelik dat Brown nie met Hume saamstem nie omdat Hume te sterk vanuit sy vooronderstellings argumenteer. Hy het eers besluit dat wonders onmoontlik is, en toe begin argumenteer.

Die standpunt van Hume het baie ná hom beinvloed. So het DF Strauss ook wonders verwerp omdat die wêreld 'n geslote sisteem van oorsaak en gevolg is en geen ingrype van 'n Hoërhand toelaat nie. Die wonders is hoogstens 'n produk van die 'myth-making mind' van die evangeliste (Brown 1984: 119-20). Ludwig Feuerbach (1804-1872) beskou ' $n$ wonder as ' $n$ '... supranaturalistic wish realised - nothing more' (aangehaal deur Brown 1984: 124). Brown (1984: 126) kom tot die gevolgtrekking dat die grondliggende standpunt van diegene wat meen dat wonders wetenskaplik gesien, onmoontlik is, byvoorbeeld Strauss, Feuerbach, Hume, Spinoza en baie ander, daarop neerkom dat dit die wette van die natuur oorskry. Brown (1984: 129) formuleer dit soos volg: 'From Celsus to Feuerbach and beyond to the present day, the objections to miracles are essentially variations on this theme.' Ook pogings om die wonders te rasionaliseer, is 'n variasie op dié tema. So het Rudolf Bultmann (1884-1976) probeer om wonders aanvaarbaar te makk vir die mens van vandag (Brown 1984: 248-53). Alles wat in die natuur gebeur, word deur wette beheer. Wonders is vir die moderne mens onaanvaarbaar, want dit word deur die universele geldigheid van die natuurwette weerspreek. Wonders was deel van die wêreldbeeld van die eerste-eeuse kerk wat alles in mitologiese terme uitgedruk het. 
Daarom het Bultman gekom met sy bekende idee van 'demitologisering'. Hiervolgens moes die wonders gestroop word van alle mitologiese terme om só by die punt of die boodskap van die wonder uit te kom. So kan wonders vandag verstaanbaar gemaak word. Tog is hierdie standpunt net nòg 'n variasie op die eeue-oue standpunt wat wonders teen die wette van die natuur is, en derhalwe onmoontlik is. (Tog is dit ironies dat Bultmann die moontlikheid van ' $n$ wonder nie heeltemal uitsluit nie. Hy sê dat daar één wonder is en dit is die wonder van die openbaring van die genade van God en die wonder van vergewing van sondes wat uit die genade van God voortspruit - EJV.)

Uit die aard van die saak het Brown hom nie alleen besig gehou met die bespreking en evaluasie van standpunte teen wonders nie - ook die voorstanders van wonders kom onder die vergrootglas. Die verdedigers van wonders ('apologete', soos Brown na hulle verwys) kan in twee kampe verdeel word (Brown 1984: 197). Eerstens is daar die sogenaamde 'offensiewe kamp' (ook 'evidentialists' genoem). Tweedens kry ons die sogenaamde 'defensiewe kamp'. Vir die eerste groep is die wonders objektiewe gebeure wat onweerlegbare bewys lewer van goddelike ingrype in die geskiedenis en die natuur. Verder bied die wonders objektiewe grond vir die geloof. Die wonders onderskryf en bewys die waarheidsaansprake van die Bybel en die geloof. Dit bewys verder die gesag van die leer en lewe van Jesus. Een van die eerste verteenwoordigers van hierdie standpunt was Origenes (185-254). Volgens Brown (1984: 4) was hy die grootste onder die 'apologete' (1984: 4). Volgens Origenes het die wonders gesag gegee aan die leerstellings van Jesus en later aan dié van die apostels. Die wonders bewys die Goddelikheid van Jesus. Maar Origenes het verder gegaan as om hom te beperk tot die wonders van Jesus. Volgens hom was dit moontlik dat wonders ook ná Jesus se tyd kon plaasvind. Dit kon gebeur deur mense wat in die voortgaande krag van Christus optree. Sulke mense besit dieselfde Gees as dié wat Jesus daartoe in staat gestel het om wonders te doen. Daarom kon die apostels wonders doen. Trouens, die apostels sou nooit die eerste hoorders kon oortuig van die nuwe leerstellings aangaande Jesus Christus sonder om wonders te doen nie. Sonder wonders sou die apostels nie die nie-Christene kon oortuig om hulle ou gevestigde tradisionele godsdienste te laat vaar en die leerstellings van die apostels te aanvaar, met risiko om só hulle lewe te verloor nie. Ook ná die apostels kan daar mense wees wat in dié voortgaande krag van Jesus steeds wonders doen. Hierdie siening het lank na Ori- 
genes die basis van die uitsprake van die meeste Rooms-Katolieke teoloë gebly.

Van tyd tot tyd het die Roomse Kerk die evidensiële karakter van wonders bevestig, soos duidelik blyk uit 'n uitspraak van die Eerste Vatikaanse Konsilie (1869-1870), dat wonders en profesieë '... so excellently display God's omnipotence and limitless knowledge, they constitute the surest signs of divine revelation, signs that are suitable to everyone's understanding' (aangehaal deur Brown 1984: 140).

Die sogenaamde 'evidensialistiese' standpunt ten opsigte van wonders, het beide onder Roomse en Protestantse teoloë voorgekom. Johannes Calvyn (1509-1564) moet ook hieronder gereken word. Brown (1984: 15) stel dit soos volg: 'On the one hand, he pointed out that the gospel was attested by miracles. On the other hand, he insisted that where a miracle is associated with false teaching, it should be dismissed as Satanic deceit.' Ware wonders bring eer aan God, pseudowonders bevorder die eer van mense. Calvyn staan dus wel in die evidensialistiese tradisie, maar nie soseer as ' $n$ 'harde evidensialis' nie, eerder as 'n 'gekwalifiseerde evidensialis'. So staan John Locke (1632-1704) ook in die evidensialistiese tradisie. Tog beskou hy nie alle bo-natuurlike gebeurtenisse as bewys van goddelike ingrype nie. Die boodskap wat saam met die wonder gaan, moet '... rational, moral, honouring to God, and not contradicting other divine revelations' wees (Brown 1984: 55). Die bepalende faktore by die bepaling van 'n wonder as bewys van goddelike ingrype was 'n morele en teologiese oorweging wat die voorskrifte van Deuteronomium 13 gevolg het. Nietemin is beide Calvyn en Locke se standpunte variasies op die tema van die 'offensiewe kamp'.

Deur die loop van jare het daar gereeld klemverskuiwings plaasgevind. Dit bring ons by die tweede kamp onder die verdedigers van wonders, naamlik die sogenaamde 'defensiewe kamp'. Hierdie kamp glo ongetwyfeld in die moontlikheid van wonders. Hulle dink egter nie dat dit moontlik is om 'harde' historiese getuienis te bied om sodoende aan te toon dat die Bybelse wonders werklik gebeur het nie. Wonders kan egter ook nie op so ' $n$ manier aangewend word dat dit die geloofwaarhede (openbaring van God, God-drie-enig, die Godheid van Jesus - EJV) kan bevestig of bewys nie. Wonders word geëvalueer vanuit die breër visie van die geloof in God. Eers is geloof nodig, daarna kan die wonders geëvalueer word. Hierdie groep 'apologete' het hulle wortels so ver terug as Augustinus (354-430), biskop van Hippo. Vir hom, anders as Origenes, was wonders nie die bewys van die Goddelikheid 
van Jesus nie. Wonders vorm nie die basis van geloof nie, dit is wel deel daarvan. Soos Brown (1984: 9) dit stel: 'What Augustine offers is a world view in which miracles can be seen to have a part. But the view itself is an explanation offered from the standpoint of faith' (1984: 9). Wonders word dus nie as geisoleerde dade uitgesonder nie, maar kry 'n plek in 'n wêreldbeeld met God as fundamentele realiteit. Deur die loop van die eeue het menige teoloog min of meer dieselfde standpunt gehuldig. Wonders gebeur, maar kan nie die leerstellings van Jesus en die kerk bewys nie. Samuel Clarke het in 1705 in ' $n$ lesing beweer dat ons nie die sirkelargument kan handhaaf dat die leerstellings deur die wonders en die wonders deur die leerstellings bewys kan word nie: 'The Doctrine must be in itself possible and capable to be proved, and then Miracles will prove it to be actually and certainly true' (aangehaal deur Brown 1984: 56; beklemtoning deur Clarke). Die geloofwaardigheid van die leerstellings hang dus nie van die wonders af nie. Tot in die twintigste eeu word hierdie standpunt gehuldig. So kom Alan Richardson se standpunt daarop neer dat die wonders van Jesus vir die NuweTestamentiese skrywers tekens was om meer van Jesus se persoonlikheid te wete te kom. Hierdie tekens was deel van die openbaring en nie objektiewe bewyse wat die openbaring waarborg, losstaande van die geloof nie (Brown 1984: 225; Brown sluit in sy eie standpunt hierby aan, kyk later).

Dit is dus duidelik dat niemand in die 'defensiewe kamp' die geloof in God op wonders as sodanig baseer nie. Die wonders word eerder geinterpreteer as tekens wat in ' $n$ reeds bestaande raamwerk van die geloof inpas. Ook in hierdie kamp is daar variasies. Daar is die standpunt dat wonders nie noodwendig radikaal van alledaagse gebeure hoef te verskil nie; dit is gebeure waarvan die oorsaak alleen nog onbekend is. Wonders word wel aanvaar as werklike gebeure, maar is ongewoon en onverklaarbaar binne die normale, natuurlike gang van sake. Ons kan John Donne $(1571-1631)$ as voorbeeld neem (Brown 1984: 28). Die natuur is nie ' $n$ afsonderlike entiteit nie. Dit is die werk van goddelike voorsienigheid. Donne sien geen radikale verskil tussen gebeurtenisse wat ons elke dag in die natuur sien en ongewone gebeure wat ons 'wonders' noem nie. Omdat God die verloop van die natuur geskape het, is daar geen verskil tussen die natuur en buitengewone gebeurtenisse nie. Donne staan dus eweneens in die Christelike tradisie wat die wonders èn die natuur binne die konteks van die geloof in God sien.

Dit wil dus voorkom asof daar deur die eeue heen slegs drie basiese 
argumente ten opsigte van die moontlikheid al dan nie van wonders bestaan. Al die verskillende filosowe en teoloë deur die eeue heen het een of ander variasie op een van die drie temas gehad. Opsommend kan dit soos volg weergegee word: Eerstens, die argument bestaan dat wonders onmoontlik is omdat dit on onversoenbaar is met ons ervaring van die werklikheid of omdat dit teen die wette van die natuur is. Tweedens, daar is die standpunt van die sogenaamde 'evidensialiste': Wonders as sodanig bestaan los van die geloof en bewys die Bybelse waarhede. Derdens, daar bestaan ' $n$ basiese mening dat wonders aanvaar word as deel van die openbaring van God en as sodanig bewys dit niks: Wonders is deel van die raamwerk van die geloof. Dit is in laasgenoemde tradisie dat Colin Brown staan.

\section{DIE BYDRAE VAN BROWN TOT DIE DEBAT OOR WONDERS}

Die basiese verskil tussen die gelowiges ('apologete' - EJV) en die skeptici, is 'n verskil in verwysingsraamwerk ('frames of reference'). Die kern van die skeptici se argument is dat daar geen analogie bestaan tussen wonders en ons ervaring nie. (Die gelowiges erken wel so 'n analogie - EJV). Wanneer die skeptikus eers tot die oortuiging gekom het van wat moontlik (of onmoontlik) is, vereis dit baie sterk oortuigingskrag en kragtige argumente om dit te verander. Tog is die gedagteprosesse (thought processes) van die gelowiges dieselfde as dié van die skeptici. Ook die gelowiges het gevestigde oortuigings in verband met die werklikheid. Dit bepaal wat vir die gelowige moontlik en waar is. Die groot probleem met hierdie twee benaderings is dat, wanneer daar eers standpunt ingeneem is, niks toegelaat word om daarteen te tel nie.

Die kritiek wat Brown teen die meeste 'apologete' het, is dat hulle te selektief te werk gaan in die keuse van wonders. Net sekere wonders word gekies in ondersteuning van hulle eie argumente. (Dieselfde kan natuurlik ook van die skeptici gesê word - EJV). Die sogenaamde 'harde evidensialiste' (wat in die wonders objektiewe bewyse van goddelike gesag soek), is te simplisties. Brown (1984: 284) stel dit soos volg: 'We do not have to look far in the writings of the evidentialists before we find them making all kinds of theological presuppositions about the nature of God and his purposes for the world in order to explain the feasibility of the miracle stories.'

Maar ook die skeptici benader die wonders met vooronderstellings wat die lees en interpretasie daarvan beïnvloed. Brown (1984: 284) merk tereg op: 'Whether we take a sceptical or a believing attitude to 
the miracle stories, we have to recognize a reciprocal relationship between our view of the stories themselves and our wider view of reality.' Al twee groepe het 'n vooronderstelling wat geslote is. Dit laat geen ruimte vir ' $n$ verbreding of uitbreiding van hulle onderskeie verwysingsraamwerke nie. Dit is ' $n$ fout, want '... only those whose thoughts remain petrified do not modify and amplify their world views as they grow in experience and insight' (Brown 1984: 285). Brown wil dus tereg hê dat 'n mens oop moet wees vir oortuiging en nie in bepaalde vooronderstellings moet versteen nie.

Brown betoog dat by die interpretasie van die wonders daar altyd gevra sal word na wat die evangeliste daarmee bedoel het. (Hy sluit hier aan by Richardson.) Ons moet erken dat die wonders in die evangelies rapporte is van die evangeliste. Daar is ongeveer 2000 jaar tussen dié gebeure en ons. Ons het egter geen direkte toegang meer tot die werklike gebeure nie. Selfs al sou die wondergebeure deur 5000 manuskripte van die Nuwe Testament weergegee word, is dit nog nie 'n waarborg dat die gebeure waar is nie - net so min as wat 5000 kopieë van 'n koerant die waarheid van 'n voorbladberig waarborg. Ons glo aan die wonders omdat ons die Skrif aanvaar en nie omdat die wonders die Skrifwaarhede bewys nie. Maar alhoewel ons nie die Christelike geloof op die wonders kan baseer nie, moet ons tog ' $n$ wonderwerkende Jesus in die geloof aanvaar. Die rede is dat as ons nie ' $n$ wonderwerkende Jesus aanvaar nie, die alternatief nie die 'etiese leermeester van die liberale teologie' is nie, maar ' $n$ historiese skeptisisme. Daar is geen manier waarop ons die wonderverhale van die evangelies los kan koppel om by 'n nie-wonderwerkende Jesus uit te kom nie.

Volgens Brown het die evangeliste nie bedoel om deur die wonders objektiewe bewyse te lewer van die Goddelikheid van Jesus nie. Hulle het die wonders vertel om die leser se oog te fokus op God die Vader, deur wie die Seun optree, en op die Seun, in verhouding tot die Vader. Die wonderverhale dra by tot die verstaan van Jesus, maar ook tot die verstaan van God. Die wonders is vir Brown 'n teken dat God deur Jesus werk. Die klem val op 'teken' en nie op 'bewys' nie. Dit kom daarop neer dat ons éérs moet aanvaar (in die geloof - EJV) dat God deur Jesus werk en dan vind ons bevestiging daarvan in die wonders. Dit is iets anders as om te beweer dat die wonders bewys dat God deur Jesus werk en dáárom aanvaar ons dit. (Dit is duidelik dat Brown ook argumenteer vanuit sy eie vooronderstelling, naamlik dat die wonders aan die evangelies en die bedoeling van die evangeliste gekoppel moet bly, en dat die wonders aan die opstanding van Jesus gekoppel is.) 
Brown (1984: 287-288) koppel die wonderverhale verder aan die opstanding van Jesus: 'The resurrection of Jesus is the ultimate vindication by God the Father of Jesus, whom he had attested by signs, wonders, and the Holy Spirit during his lifetime.' Jesus is gekruisig omdat hy volgens die Jode onder die vloek van God gestaan het. Volgens Matteus 26:65 en Markus 14:64 was Jesus se aanspraak dat Hy die Messiaanse Seun van God was, die deurslaggewende faktor vir sy veroordeling. Hierdie aanspraak was vir die hoëpriester 'n daad van Godslastering. Dit was 'n oortreding wat die doodstraf waardig was (vergelyk Lev 24: 16). Die gebruik van God se naam in towenary, sowel as onwettige vervloeking, kon ook die doodstraf opgelê word (vergelyk Eks 20: 7). So was deelname aan heksery, okkulte of buitelandse afgodery ook met die dood strafbaar (sien Deut 13: 1-18). Die Jode het Jesus beskou as iemand wat met die okkulte besig was en daarom op grond van Deuteronomium 13 regverdiglik met die dood gestraf kon word. Brown meen dat die Christelike kerk nooit die waarde van Deuteronomium 13 ten volle na waarde geskat het ten opsigte van die Jode se verstaan van Jesus nie. Vir die Joodse leiers was die wonders duidelike bewyse van skuld. Dit was vir die Jode 'n teken dat die Satan in Jesus werksaam was en daarom vir hulle genoegsame getuienis om die kwaad uit hulle midde te suiwer. Daarteenoor was die opstanding van Jesus as 't ware God se verdediging en verheffing van die Een in wie Hyself (en nié die Satan, soos die Jode gedink het nie), al die tyd werksaam was. Dit is daarom korrek dat die 'apologete' die opstanding as ' $\mathrm{n}$ historiese gebeurtenis en as sodanig as die hoeksteen van die Christelike geloof aanvaar het. Dit is nie 'n wonder langs die ander wonders nie, maar wel 'n seël op alles wat Jesus was en is. Die opstanding dien nie as 'n toets vir die aanvaarding van die ander wonders nie, maar toon tog oortuigend dat al die ander aktiwiteite van Jesus ook die werk van God was: "The resurrection of Jesus is related to the miracles of Jesus in the sense of identifying and confirming the truth that "God was with him"' (Acts 10: 88) (Brown 1984: 289).

\section{EVALUASIE}

Dit wil dus voorkom of Brown die opstanding van Jesus en die koppeling van die wonders aan die opstanding, wil gebruik om die persoon van Jesus te verstaan. Die wonders, gekoppel aan die opstanding, gee aan hom die sleutel vir die verstaan van Jesus, en waarom die Jode Jesus wou kruisig (Brown 1984: vii). Die Jode het Jesus gekruisig omdat 
hulle in die wonders bewyse gesien het dat die Satan in Hom werk. Daarteenoor het die opstanding die teendeel getoon. Die opstanding en die wonders is vir Brown 'n bevestiging dat God met Jesus was, en nie die Satan nie. Myns insiens is dit'n interessante perspektief wat hy op die wonders plaas. As sodanig is dit, tesame met die vraag na die bedoeling van die evangeliste met die wonders, ' $n$ insiggewende bydrae wat Brown tot die debat oor die wonders lewer.

Ongelukkig slaag Brown nie daarin om nuwe insigte te lewer ten opsigte van die historisiteit van wonders, of die wonders van Jesus nie. Hy staan ook in die tradisie dat wonders in die geloof aanvaar moet word en dat ons die wonders van Jesus aanvaar omdat dit in die Bybel opgeteken staan. Hy weerspreek homself egter ten opsigte van die opmerking wat hy in sy inleiding maak: '... the miracle stories themselves are what enables us to make sense of the Gospel as history' (1984: vii; beklemtoning deur Brown). Hy slaag nie daarin om aan te toon dat die wonders historiese gebeurtenisse was nie, tensy dit in die geloof as sodanig aanvaar word. (Sodoende staan hy in ' $n$ eeue-oue tradisie.) Ten opsigte van die wonders stel Brown die volgende: 'Where miracles of this sort (natuurwonders - EJV) are believed, they must be believed as mysteries or not at all' (1984: 290; beklemtoning deur myself - EJV). Brown (1984: 292) stel verder dat wonders nie die objek van wetenskaplike ondersoek kan wees nie. Dit geld myns insiens ook ten opsigte van die moderne geskiedskrywing as 'n wetenskap. As die wonders dan nie wetenskaplik ondersoek kan word nie en derhalwe nie histories bewysbaar is nie, maar in die geloof as misteries aanvaar moet word, kan die wonders nié bydra daartoe om die evangelies as geskiedenis ('history') te bewys nie. Trouens, ek is daarvan oortuig dat daar in die hedendaagse evangelienavorsing genoeg getuienis bestaan wat so'n stelling weerspreek.

In die teologie en die eksegese is dit bekend dat niemand die Bybel nader sonder voorafingenome vooronderstellings nie. Dit geld ook wanneer 'n mens die wonders nader. Dit is daarom niks nuuts wat Brown sê ten opsigte van die verwysingsraamwerk en vooronderstellings van die skeptici teenoor dié van die 'apologete' nie. Tog kan ons met Brown saamstem dat ons altyd die moontlikheid oop moet hou om ons insigte en ervarings uit te brei, wat op sy beurt weer ons verwysingsraamwerk sal verbreed.

Brown het al die standpunte ten opsigte van wonders chronologies probeer orden. Dit het aan hom ' $n$ handige werksmetode gebied in sy evaluasie van die verskillende standpunte. Dit het egter die nadeel dat 
dit vir die leser moeilik is om 'n geheelbeeld te vorm. Dit het die verdere nadeel dat sekere teoloë en filosowe geforseerd onder hoofopskrifte geplaas word, om by die chronologiese patroon in te pas. Die 'Puritanisme' word onder die 'Deïsme' geplaas. Ook John Locke, Samuel Clarke, Joseph Butler en ander word onder die 'Age of Deism' gevoeg, terwyl hulle nie deiste was nie. So word die Deense filosoof Soren Kierkegaard (1813: 55) onder die hoofopskrif 'Continental Skepticism' geplaas, terwyl hy alles behalwe 'n skeptikus ten opsigte van die wonders was.

Die groot waarde van Brown se studie lê in die feit dat dit 'n volledige studie is wat al die verskillende standpunte ten opsigte van die wonders probeer orden het. Derhalwe is dit ' $n$ besonder handige naslaanwerk vir diegene wat hulle wil verdiep in die studie van die wonders. Hiérin lê sy groot waarde, en nie noodwendig in sy bydrae tot die debat oor wonders nie, want Brown bied myns insiens weinig nuwe insigte. 